\section{Nauplius}

The JoURnal OF ThE Brazilian Crustacean Society

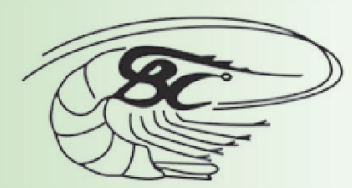

e-ISSN 2358-2936 www.scielo.br/nau www.crustacea.org.br
This article is part of the tribute offered by the Brazilian Crustacean Society in memoriam of Michael Türkay for his outstanding contribution to Carcinology

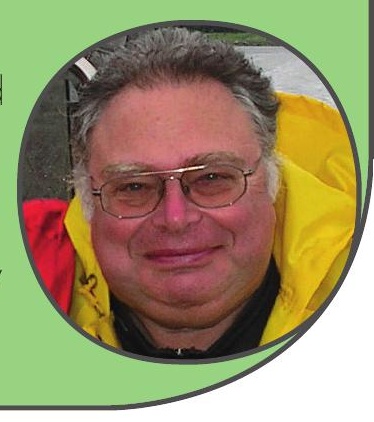

Original Article

\title{
A tribute to Michael Türkay (3 April 1948 - 9 September 2015): contributions and legacy of a lifelong study on New World decapods, and personal impressions
}

\author{
Célio Magalhães
}

Instituto Nacional de Pesquisas da Amazônia. Av. André Araújo, 2936, 69067-375 Manaus, Amazonas, Brazil.

ZOOBANK http://zoobank.org/urn:1sid:zoobank.org:pub:DB8C47F3-1725-4DB4A044-357D7926850B

\section{Abstract}

Prof. Dr. Michael Türkay, curator of Crustacea in the Senckenberg Research Institute and Natural History Museum, unexpectedly passed away on $9^{\text {th }}$ September 2015 in Frankfurt am Main, Germany. The Brazilian Crustacean Society (Sociedade Brasileira de Carcinologia -SBC, in Portuguese), taking into account Michael's outstanding contribution to carcinology, his strong interest in New World decapods (Neotropical freshwater crabs in particular), and his ties with Brazilian colleagues, decided to honor his memory and legacy with a special series of publications in Nauplius, the Society's scientific journal. In the present opening article to the SBC tribute, his contributions to the study of New World decapods, particularly freshwater ones, are reviewed, and some reminiscences of the scientific partnership and friendship with the author are presented.

CORRESPONDING AUTHOR

Célio Magalhães

celiomag@inpa.gov.br

SUBMITTED 9 June 2016

ACCEPTED 16 June 2016

PUBLISHED 9 September 2016

Guest Editor

Célio Magalhães

DOI 10.1590/2358-2936e2016012

\section{KEY WORDS}

Biography, Crustacea, freshwater crabs, Neotropical region, reminiscences.

Prof. Dr. Michael Türkay (Figs. 1, 2), curator of Crustacea in the Senckenberg Research Institute and Natural History Museum, unexpectedly passed away on 9th September 2015 in Frankfurt am Main, Germany, he was only 67 years 


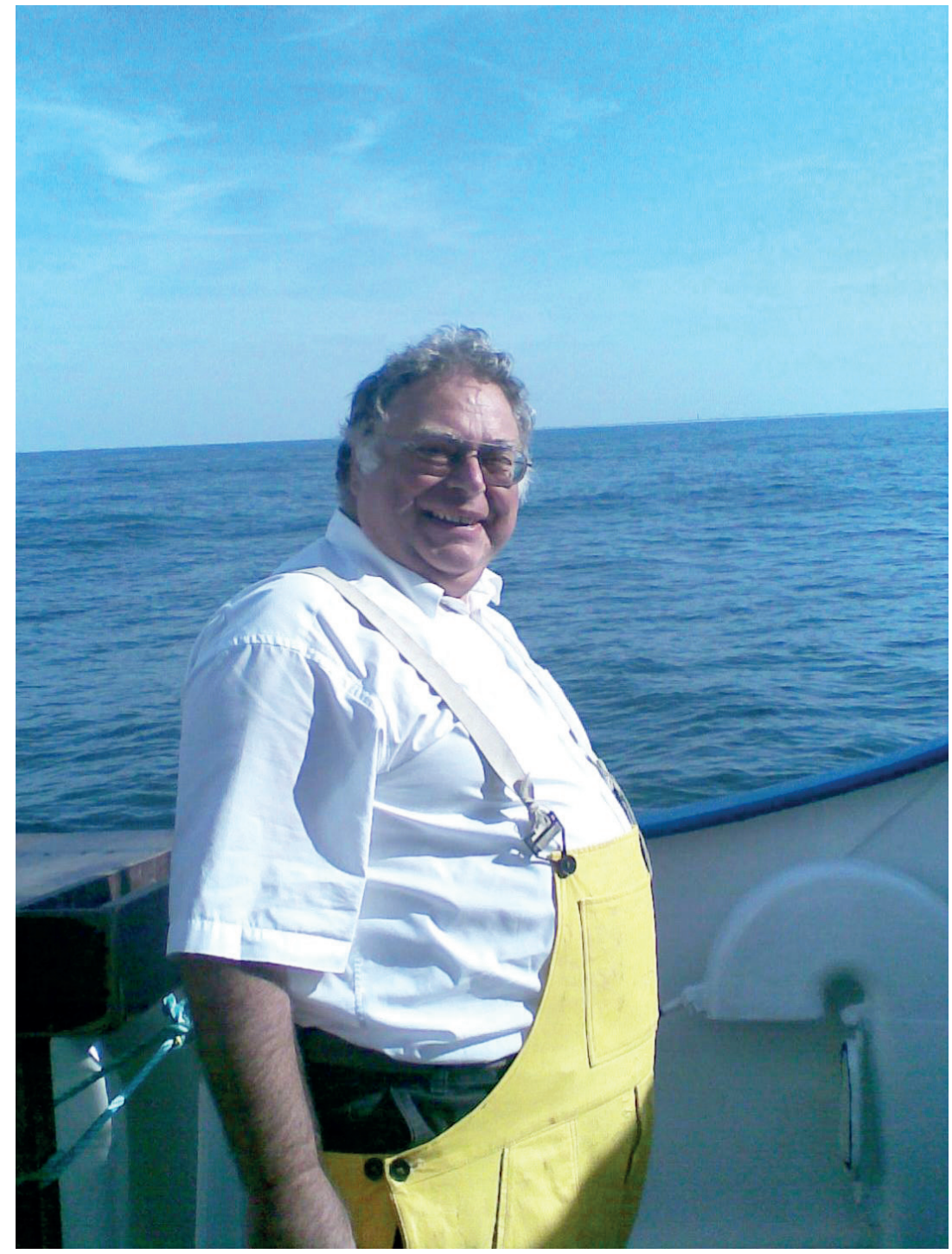

Figure 1. Michael Türkay on board of the RV Senckenberg in the North Sea, $1^{\text {st }}$ August 2007 Photo: Moritz Sonnewald.

old. The sad news of his sudden death caused strong consternation in the community, as over a period of half a century of dedication to crustacean and marine biology research he had built a very large network of friends and professional colleagues around the world.

The Brazilian Crustacean Society (Sociedade Brasileira de Carcinologia - SBC, in Portuguese), taking into account Michael Türkay's outstanding contribution to carcinology, his strong interest in New World decapods (Neotropical freshwater crabs in particular), and his ties with Brazilian colleagues, decided to honor his memory and legacy with a special volume of Nauplius, the Society's scientific journal. The SBC board of directors and the Editor-in-Chief of Nauplius honored me with an invitation, which I promptly accepted, to be the Guest Editor of this special volume, in view of the history of co-operation between Michael and me for over 30 years.

It should be noted, however, that Nauplius recently underwent a modernization process that led to some important changes in its publication system. From January 2016, papers have been published online as soon as they are accepted. Consequently, the new system does not allow the preparation of a consolidated printed issue at one given time; hence, this tribute consists of a series of articles that will follow this opening paper. All articles will contain a statement to identify them as part of the tribute as the papers are being published during 2016 and early 2017 .

Sonnewald and Apel (2016a; 2016b) presented a detailed, elegant obituary, including a biographical sketch of Michael's personal and professional life. In 
the present opening article to the SBC tribute, I will restrict myself to highlight and briefly comment on the importance and impact of his contributions to the study of New World decapods, particularly freshwater ones, and reminisce on our scientific partnership and friendship. This will serve to illustrate the charismatic personality of the scientist and the kind of person Michael was.

\section{Biographic Notes}

Michael Türkay was born on 3 April 1948 in Frankfurt am Main. After a period of living in Istanbul (1950 to 1964), where he attended primary and middle school, he returned to Frankfurt, finished the middle school and began graduation studies on October 1967 at the J.W. Goethe University on Biology and Chemistry. He received his Pre-Diploma (equivalent to Bachelor degree) on April 1970, and Main Diploma (equivalent to a Master of Science degree) on 7 November 1973 (main subject Zoology; additional subjects Botany and Organic Chemistry). At this same university, he got his Doctorate on 27 June 1983, with the thesis "Morphology and taxonomy of the Gecarcinidae. A contribution towards the comparative morphology of Brachyura (Crustacea: Decapoda)" [mentor: Prof. Dr. W. Schäfer; principal referee: Prof. Dr. K. Fiedler]. His interest in zoology and biological collection related subjects started very early and, already in 1964, at the age of 16, he was volunteering in the Senckenberg Research Institute and Natural History Museum, in the Crustacea Section under the supervision of Dr. Richard Bott (Sonnewald and Apel, 2016a). He spent his whole professional career at this institution, in which he held successive positions as Curator and Head of the Crustacean Section, Head of the Department of Marine Zoology, headmaster of the Senckenberg School, and Deputy Director, joining the Senckenberg Board of Directors from 2007 to 2013 . He formally retired on 30 June 2013, but kept his position at the Crustacean Section up to his untimely death. Michael's active participation in Senckenberg's higher administration included management in the areas of Science, Personnel and Finances.

\section{SCientific Contribution}

Michael published over 310 scientific, technical and popular science papers as author or co-author (see complete list in Sonnewald and Apel, 2016a; 2016b). The papers on systematics and taxonomy of Crustacea deal with groups from all over the world, approximately 130 of them on marine groups and 29 on freshwater groups. A total of 20 papers were exclusively dedicated to the New World decapods and concerned Antillean, Central and, mostly, South American crustaceans (see References), four of which are on marine and 16 on freshwater groups (Tabs. 1,2). In addition, alone or in co-authorship with Dr. Katsushi Sakai, he published 10 further papers on faunistics or revision of groups, which included representatives of various New World marine crabs. Across these contributions, he described eight new genera (Tab. 1), as well as 23 new species and one subspecies (Tab. 2) of American and Antillean decapods belonging to 17 families.

\section{Marine and terrestrial groups}

Michael's first three scientific publications dealt wholly with brachyuran crabs from American marine waters. In his very first paper, he presented the description of

Table 1. Genera of New World decapod crustaceans described by Michael Türkay.

\begin{tabular}{|c|c|c|c|}
\hline Family & Genus & Locality & Habitat \\
\hline Axianassidae & $\begin{array}{l}\text { Anomalaxius Sakai and Türkay, } 2012 \\
{[=\text { Axianassa Schmitt, 1924] }}\end{array}$ & USA (Gulf of Mexico) & Marine \\
\hline Gecarcinidae & Johngarthia Türkay, 1970 & Western Atlantic and Eastern Pacific & Estuarine (land) \\
\hline Ocypodidae & Hoplocypode Sakai and Türkay, 2013 & Eastern Pacific & Marine \\
\hline Pseudothelphusidae & Brasiliothelphusa Magalhães and Türkay, 1986 & Brazil & Freshwater \\
\hline \multirow[t]{3}{*}{ Trichodactylidae } & Bottiella Magalhães and Türkay, 1996a & Colombia, Venezuela & Freshwater \\
\hline & Melocarcinus Magalhães and Türkay, 1996a & Panama & Freshwater \\
\hline & Moreirocarcinus Magalhães and Türkay, 1996a & Brazil, Ecuador, Peru & Freshwater \\
\hline Varunidae & Neohelice Sakai, Türkay and Yang, 2006 & Southwestern Atlantic & Marine \\
\hline
\end{tabular}


Table 2. Species of New World decapod crustaceans described by Michael Türkay.

\begin{tabular}{|c|c|c|c|}
\hline Family & Species & Locality & Habitat \\
\hline \multirow[t]{2}{*}{ Aeglidae } & Aegla cavernicola Türkay, 1972 & Brazil & Freshwater \\
\hline & Aegla strinatii Türkay, 1972 & Brazil & Freshwater \\
\hline Axianassidae & $\begin{array}{l}\text { Anomalaxius floridanus Sakai and Türkay, 2012 } \\
\text { [=Axianassa arenaria Kensley and Heard, 1990] }\end{array}$ & USA (Gulf of Mexico) & Marine \\
\hline Callianassidae & Callichirus santarosaensis Sakai and Türkay, 2012 & USA (Gulf of Mexico) & Marine \\
\hline \multirow[t]{2}{*}{ Inachoididae } & Pyromaia vogelsangi Türkay, 1968 & Venezuela, Margarita Island & Marine \\
\hline & $\begin{array}{l}\text { Podochela botti Türkay, } 1968 \\
\text { [= Ericerodes botti (Türkay, 1968)] }\end{array}$ & Venezuela, Margarita Island & Marine \\
\hline Mithracidae & $\begin{array}{l}\text { Mithrax (Mithraculus) cancasensis Türkay, } 1967 \\
{[=\text { Mithraculus cancasensis (Türkay, 1967)] }}\end{array}$ & Peru (marine coast) & Marine \\
\hline Paguridae & $\begin{array}{l}\text { Pagurus impressus zilchi Türkay, } 1968 \\
\text { [= Manucomplanus spinulosus (Holthuis, 1959)] }\end{array}$ & Venezuela, Margarita Island & Marine \\
\hline Panopeidae & Tetrapax ortrudae Türkay, 1967 & El Salvador & Marine \\
\hline Pilumnidae & Pilumnus koepckei Türkay, 1967 & Peru & Marine \\
\hline \multirow[t]{2}{*}{ Plagusiidae } & Euchirograpsus antillensis Türkay, 1975 & $\begin{array}{l}\text { Western Atlantic, Greater } \\
\text { Antilles }\end{array}$ & Marine \\
\hline & Euchirograpsus pacificus Türkay, 1975 & $\begin{array}{l}\text { Eastern Pacific } \\
\text { (Galapagos Islands) }\end{array}$ & Marine \\
\hline Portunidae & $\begin{array}{l}\text { Portunus (Achelous) isolamargaritensis Türkay, } 1968 \\
{[=\text { Achelous isolamargaritensis (Türkay, 1968)] }}\end{array}$ & Venezuela, Margarita Island & Marine \\
\hline \multirow[t]{5}{*}{ Pseudothelphusidae } & Brasiliothelphusa dardanelosensis Magalhães and Türkay, 2010 & Brazil & Freshwater \\
\hline & Brasiliothelphusa tapajoense Magalhães and Türkay, 1986 & Brazil & Freshwater \\
\hline & Kingsleya hewashimi Magalhães and Türkay, 2008c & Venezuela & Freshwater \\
\hline & Neostrengeria botti Rodriguez and Türkay, 1978 & Colombia & Freshwater \\
\hline & Potamocarcinus darienensis Magalhães, Campos and Türkay, 2013 & Panama & Freshwater \\
\hline \multirow[t]{2}{*}{ Sesarmidae } & Sesarma fossarum Schubart, Reimer, Diesel and Türkay, 1997 & Jamaica & Freshwater \\
\hline & Sesarma windsor Türkay \& Diesel, 1994 & Jamaica & Freshwater \\
\hline \multirow[t]{3}{*}{ Trichodactylidae } & Fredilocarcinus apyratii Magalhães and Türkay, 1996c & Brazil & Freshwater \\
\hline & Goyazana rotundicauda Magalhães and Türkay, 1996c & Brazil, Ecuador, Peru & Freshwater \\
\hline & Sylviocarcinus australis Magalhães and Türkay, 1996b & Argentina, Brazil, Paraguay & Freshwater \\
\hline Upogebiidae & Upogebia hertwecki Sakai and Türkay, 2012 & Mexico & Marine \\
\hline
\end{tabular}

three new species from the western coasts of Central and South America belonging to three different groups of crabs (Türkay, 1967). In the second and third publication, he presented a compilation of species from the Margarita Island (Venezuela) in which he introduced four new species and subspecies (Türkay, 1968), and made the first comprehensive revision of the American Gecarcinidae (see Türkay, 1970) since the treatment of this group by Rathbun (1918). In the latter paper, he also introduced a new subgenus, Gecarcinus (Johngarthia) Türkay, 1970, currently recognized as a valid genus ( $\mathrm{Ng}$ et al., 2008; De Grave et al., 2009). Michael had a predilection for the study of the terrestrial decapods, for which he became widely known as an expert. In addition to the revision of the
American species, he also studied the African (Türkay, 1973a), Asian and Oceanian species (Türkay, 1974a).

Campos and Türkay (1989) recorded Charybdis hellerii (A. Milne-Edwards, 1867) from the Caribbean coast of Colombia, which was the first published report about the occurrence of this Indo-Pacific portunid crab in western Atlantic waters. They hypothesized that the most probable origin for the specimens found in Colombia was the Israeli coast, and postulated that the success of the introduction could only be assessed in the future. This publication was eventually followed by a steady stream of papers recording this species from Florida (USA) to Santa Catarina (southern Brazil) (Lemaitre, 1995; Mantelatto and Dias, 1999; Tavares, 2011; Bentes et al., 2013; Rosa, 2014; see 
other references therein) and this alien species has now indeed successfully established itself in the western Atlantic.

Additionally, representatives of the New World marine decapods were also included in other papers with a broader geographic scope dedicated either to revisions of some groups or reports on material found in zoological collections, particularly that of the Natural History Museum of Geneva - MHNG (Sakai and Türkay, 1977; 2012; 2013; 2014; Sakai et al., 2006; Türkay, 1971a; 1971b; 1973b; 1974b; 1975). These papers, in addition to providing valuable data on geographic distribution, also conveyed important taxonomic information for several different groups. Among those, it is worth calling attention to at least four in which new taxa were introduced. In an account on the taxonomy of Euchirograpsus $\mathrm{H}$. Milne Edwards, 1853, a widely distributed genus of Plagusiidae, he described two new species (Türkay, 1975): Euchirograpsus antillensis Türkay, 1975, from the western Atlantic and Greater Antilles (southern Bahamas, Florida Keys and Cuba), and Euchirograpsus pacificus Türkay, 1975, from the eastern Pacific Ocean, in the Galapagos Islands (Ecuador), and redescribed in detail the then poorly known Euchirograpsus americanus A. Milne-Edwards, 1880. This study was important in that it recognized that two sympatric species of the genus occur in the western Atlantic, clearly showing the morphological differences between $E$. antillensis and $E$. americanus, and delimiting their distributions.

One of the most important outcomes of the revision of the Helice/Chasmagnathus complex (Sakai et al., 2006) for the Neotropics concerned Neohelice granulata (Dana, 1851), a very common species inhabiting the intertidal zones of estuaries, salt marshes and mangroves in the tropical and subtropical southwestern Atlantic, occurring from the state of Rio de Janeiro, Brazil, to Buenos Aires, Argentina. The species is among the most studied crab species and often used as a model species for biological, ecological, physiological, toxicological and behavioral research (see Spivak, 2010). Formerly included in Chasmagnatus De Haan, 1835, the species was transferred to the newly-described Neohelice Sakai, Türkay and Yang, 2006, based on a detailed morphological study in which the authors used a set of characters from the endophragmal system, stridulating apparatus, gastric mill and copulatory structures.
In a report on the collection of Thalassinidea deposited in the Senckenberg Museum (Sakai and Türkay, 2012), a new genus, Anomalaxius Sakai and Türkay, 2012, and three new species, Anomalaxius floridanus Sakai and Türkay, 2012, and Callichirus santarosaensis Sakai and Türkay, 2012 (both from the Gulf of Mexico: USA, Florida, Santa Rosa Island), and Upogebia hertwecki Sakai and Türkay, 2012, from Mexico (Sonora state, Puerto Penasco), were described. This paper also reported on the occurrence of a number of species of Callianassida and Thalassinida in the eastern and western coasts of America. However, the validity of the first two species was recently questioned by Felder and Dworschak (2015), who found that the type material of Anomalaxius floridanus is actually a mutilated juvenile of Axianassa arenaria Kensley and Heard, 1990, and synonymized both under Axianassa Schmitt, 1924. Felder and Dworschak (2015) also suspected that the fragmented holotype of $C$. santarosaensis could be a known species as they could not find a morphological adult character to clearly distinguish it from Callichirus major (Say, 1818). However, on the basis of the geographical origins of the material (distinct areas of the Gulf of Mexico), the name of C. santarosaensis was provisionally kept until further collections and/or a genetic analysis can resolve this issue more conclusively.

Michael's fruitful scientific partnership with $\mathrm{K}$. Sakai also produced an important contribution to the taxonomy of another group with well-known representatives in American waters in a revision of Ocypode Weber, 1795, a tropical and subtropical widely distributed group popularly known as ghost crabs, very common on sandy beaches worldwide. After a thorough morphological study (Sakai and Türkay, 2013), they recognized a new genus, Hoplocypode Sakai and Türkay, 2013, with a single species, Hoplocypode occidentalis (Stimpson, 1860), restricted to the eastern Pacific Ocean from the Gulf of California to Colombia. They also redefined Ocypode as containing 21 species from the Mediterranean, as well as the Atlantic, Indian, and Pacific Oceans. The new genus was established based on the peculiar morphology of the male first gonopod of $H$. occidentalis, characterized by a complex hoof-shaped tip, in contrast with the simple and curved tip found on the gonopod in the species of Ocypode. By that action, they included a second genus in the 
then monogeneric Ocypodinae. Furthermore, they made clear the distinction between $H$. occidentalis and Ocypode gaudichaudii H. Milne Edwards and Lucas, 1843, as both species have partially sympatric distributions in the eastern Pacific from Central to South America. In addition, they presented a detailed synonymy, a morphological description and an extensive list of material examined for each species, which of course also included the well known Ocypode quadrata (Fabricius, 1787) which is extensively distributed along the western Atlantic from the state of Massachusetts (USA) to the state of Rio Grande do Sul (southern Brazil).

\section{Freshwater groups}

Apart from the above-mentioned papers on marine groups, all other publications concerning New World decapods authored and co-authored by Michael Türkay dealt with freshwater crabs. In his only paper on Aeglidae, the endemic South American anomuran family, he described two new species of Aegla from caves in São Paulo state, Brazil (Türkay, 1972). Those two species, Aegla cavernicola Türkay, 1972, and Aegla strinatii Türkay, 1972, were the first aeglids to be found in caves. The former is indeed a troglobitic species, but the latter is now known to be troglophile as it was subsequently found in epigean environments as well (Bond-Buckup and Buckup, 1994; Rocha and Bueno, 2004). Michael was generally less excited by anomurans, and this paper was somewhat incidental, made at the request from a friend who had sent him the material (L. Buckup, pers. comm.).

The sesarmid freshwater crabs from Jamaica were treated in two papers and a new species was described in each one (Türkay and Diesel, 1994; Schubart et al., 1997). In the first paper, the authors introduced Sesarma windsor Türkay and Diesel, 1994, on the basis of several specimens from different localities occurring in burrows in a river banks and in a cave. Later, the type material of this species was re-examined and found to belong to two different forms: the holotype of S. windsor represented a form only recorded from a freshwater cave, whereas the other specimens belonged to a form that inhabits burrows in the banks of mountain creeks and were assigned to a new species, Sesarma fossarum Schubart, Reimer, Diesel and Türkay, 1997 (see Schubart et al., 1997).
However, one of the main focal points of Michael's contributions to the knowledge of the taxonomy and systematics of American decapods were the primary freshwater crabs. These belong to those brachyuran families whose representatives have adopted freshwater, semi-terrestrial, or terrestrial modes of life, and which reproduce by direct development (Yeo et al., 2008; Cumberlidge and Ng, 2009). He published, alone and in collaboration with South American colleagues, seven papers on the Pseudothelphusidae and six on the Trichodactylidae (see References). His first collaborative study on pseudothelphusid crabs was with Dr. Gilberto Rodríguez, a Venezuelan carcinologist who was then preparing his monograph on this family (Rodriguez, 1982). At the time, the systematics of freshwater crab families was in a very confused state, partly because the acrimonious relationship between the then established experts, Dr. Richard Bott, from Senckenberg, and Dr. Gerhard Pretzmann, from the Vienna Museum of Natural History (Dworschak, 2014). Their personal dislike of each other greatly contributed to that unfortunate situation. In a joint paper, Gilberto and Michael clarified the taxonomic status of two Colombian genera, Neostrengeria Pretzmann, 1965, and Phallangothelphusa Pretzmann, 1965, established the specific delimitation of Neostrengeria lindingiana (Rathbun, 1897) and Phallangothelphusa dispar (Zimmer, 1912), which included the designation of a lectotype for the former, and described Neostrengeria botti Rodriguez and Türkay, 1978, as a new species (Rodriguez and Türkay, 1978). In the same year, Michael published, as a single author (Türkay, 1978), on the taxonomy of the subgenus Pseudothelphusa (Tehuana) Rodríguez and Smalley, in Smalley (1970), in which he recognized three species: Pseudothelphusa (Tehuana) lamellifrons Rathbun, 1893, Pseudothelphusa (Tehuana) veracruzana Rodríguez \& Smalley in Smalley, 1970, and Pseudothelphusa (Tehuana) complanata Rathbun, 1905, considering Pseudothelphusa (Pseudothelphusa) lamellifrons gruneri Pretzmann, 1968b, and Pseudothelphusa (Tehuana) cordobensis Rodríguez \& Smalley, 1972 as junior synonyms of the latter (Türkay, 1978). By resolving the confusion regarding the type locality of Tehuana complanata, Michael's study was important to establish the taxonomic identity of this taxon and the specific composition of the subgenus (currently a valid genus, according to Rodriguez, 1982). 
All the remaining papers by Michael on Neotropical crabs resulted from a fruitful scientific collaboration between him and the present author, established some 30 years ago (see below). The first one was significant because, in addition to describing Brasiliothelphusa tapajoense Magalhães \& Türkay, 1986, a new genus and species of a pseudothelphusid crab from the Tapajós River, it also contributed the first record of the family from a southern tributary of the Amazon River (Magalhães \& Türkay, 1986). At that time, Brazilian pseudothelphusids were very poorly known and it was believed that the distribution of the family in eastern South America was restricted to the region north of the main channel of the Amazon River (Bott, 1969b; Pretzmann, 1973). Magalhães \& Türkay (1986) also commented on Rodriguez's (1982) hypothesis about the origin and dispersion of the tribe Kingsleyini in South America. Based on the structural plan of the male first gonopod, his hypothesis suggested a colonization history in which the northwestern forms of the tribe would be the most primitive and, from there, had dispersed to the eastern part of South America. Following - and agreeing - with Rodríguez's ideas on the structure of the gonopod, Magalhães \& Türkay (1986) found that the new taxon from Tapajós River would be more primitive than the northwestern forms, demonstrating that the evolutionary history of the Pseudothelphusidae in eastern South America is more complex than at first thought.

Michael's contribution on the taxonomy and diversity of the South American pseudothelphusid crabs continued with the description of Kingsleya hewashimi Magalhães and Türkay, 2008c, from the upper reaches of the Orinoco basin, this being the first record for the genus from Venezuela (Magalhães and Türkay, 2008c). Not long after, he also contributed a paper that revalidated Eudaniela (Kunziana) Pretzmann, 1971a. This monotypic subgenus was introduced by Pretzmann (1971a) with a very brief description of Eudaniela (Kunziana) irengis Pretzmann, 1971a, from Guyana. This species was listed as incerta sedis in Rodriguez's (1982) monograph because he could not examine the type material (considered as being lost by the repository institution, the Natural History Museum, London) and he judged Pretzmann's (1971a; 1972) superficial descriptions to have little diagnostic value. The rediscovery of the type material and the nearly simultaneously availability of new material from Guyana allowed the redescription of the species and the recognition that Kunziana was indeed a valid taxon (Magalhães et al., 2009).

Important taxonomic and zoogeographic results for which Michael made valuable contributions were published in the following two articles. A second species of the Brasiliothelphusa, Brasiliothelphusa dardanelosensis Magalhães \& Türkay, 2010, was described from the Aripuanã River, in the state of Mato Grosso, Brazil (Magalhães \& Türkay, 2010). This species occurs further south than B. tapajoense, thus corroborating previous suspicions that the pseudothelphusids have indeed a greater diversity and distribution in the southern reaches of the Amazon basin. However, the recent finding of a new species from a nearby locality in the northern Mato Grosso state and a phylogenetic study of the Kingsleyini by Dr. M. Pedraza showed that Brasiliothelphusa dardanelosensis should be moved to another as yet undescribed genus in order to accommodate it (Pedraza, Tavares and Magalhães, unpublished data).

Michael's partnership was also valuable in studying the Central American freshwater crabs. Despite being a small country in surface, Panama harbors a relatively high diversity of these crabs, but the knowledge about them is somewhat fragmentary and very little was known about the fauna occurring in the more remote, southeastern part of the country. The paper by Magalhães et al. (2013) reported new information about two little known species from that region, Spirocarcinus garthi (Pretzmann, 1971b) (Pseudothelphusidae) and Melocarcinus meekei (Pretzmann, 1968a) (Trichodactylidae), and described a new one, Potamocarcinus darienensis Magalhães, Campos and Türkay, 2013 (Pseudothelphusidae). Spirocarcinus garthi was until then, only known from the type locality in central Panamá (Pretzmann, 1971b), but the study of specimens in the Senckenberg Natural History Museum and the U.S. National Museum of Natural History (Washington, D.C.) extended its range towards the southeastern part of the country and allowed a detailed redescription of the male first gonopod morphology. Those results, and particularly the description of $P$. darienensis, showed that the Darién Province, in southeastern Panama, is a very interesting region in terms of both freshwater crab diversity and 
biogeographical connections with northwestern Colombia.

Perhaps the most valuable among Michael's many contributions to the study of the Neotropical freshwater crabs has been the taxonomic revision of the Trichodactylidae. This revision was the focus of our scientific co-operation and was planned as a series of publications from the outset (see below). The first outcomes of this partnership appeared in three consecutive papers published in the same issue of the Senckenbergiana biologica in 1996. Back in the mid-1980's, when we outlined the study, the systematic status of the family was in a confusing situation, similar to that of the pseudothelphusids before Rodriguez's (1982) monograph; especially since two different classification systems had been proposed nearly simultaneously by Pretzmann (1968a; 1968c) and Bott (1969a). At that time, we also did not realize that Gilberto Rodríguez was also independently revising the trichodactylids. The resultant monograph by Rodríguez (1992) on the Trichodactylidae was an important work with the classification based on a cladistic analysis. However, his study was hampered by the unavailability of some material, the small numbers of specimens examined for several species, and the inability to examine the type material of several key nominal species. The first part of our revision was dedicated to our proposed classificatory system of the trichodactylids at generic and supra-generic levels (Magalhães and Türkay, 1996a). Although not based on a cladistic analysis, the proposed system was based on a careful and comprehensive morphological comparative analysis including important characters of the carapace, structures related to respiration, abdomen, thoracic sternum, axial skeleton, and the male first gonopod. The main difference of our approach to that of Rodríguez (1992) was that we put a strong emphasis on the features of the axial skeleton and did not treat the single features as individual independent characters but as functional complexes instead. Although both systems were generally similar, the supra-generic system proposed by Magalhães and Türkay (1996a) [Trichodactylidae (Trichodactylinae + Dilocarcininae (Dilocarcinini + Valdiviini))] was somewhat more inclusive than that by Rodríguez (1992), who recognized Holthuisini as a third tribe within Dilocarcininae. In contrast, Rodríguez's system was more inclusive at the generic level, as we split Dilocarcinus H. Milne Edwards, 1853, into five genera in our system, describing two as new: Bottiella Magalhães and Türkay, 1996a, and Moreirocarcinus Magalhães and Türkay, 1996a. A third new genus, Melocarcinus Magalhães and Türkay, 1996a, in Valdiviini, was also introduced at the same time. Through the initiative of Michael, in view of the unavailability of material for anatomical preparations of the type species of all genera, we employed radiography (X-rays) to examine the axial skeleton of some species. It was the first time that such a technique was used in systematic studies of Neotropical freshwater crabs, indeed for any freshwater crab. Later, a more detailed anatomical study of the axial skeleton of the family by Pedraza et al. (2015) corroborated the supra-generic system proposed by Magalhães \& Türkay (1996a).

The taxonomic revision of two groups of genera was published soon after. In the first paper (Magalhães and Türkay, 1996b), four genera of Valdiviini were treated: Forsteria Bott, 1969a (one species), Melocarcinus Magalhães and Türkay, 1996a (one species), Sylviocarcinus H. Milne Edwards, 1853 (four species), and Zilchiopsis Bott, 1969a (three species). A new species, Sylviocarcinus australis Magalhães and Türkay, 1996b, was also described to separate the southern form from the closely related northern form assigned to Sylviocarcinus pictus (H. Milne Edwards, 1853). Sylviocarcinus australis is distributed in the Paraguaylower Paraná River systems whereas, at that time, $S$. pictus was supposedly confined to the Amazon basin. However, the latter species has now also been found in the Paraná River (Collins et al., 2009). A second paper (Magalhães and Türkay, 1996c) dealt with two genera of Dilocarcinini, Fredilocarcinus Pretzmann, 1978 (three species) and Goyazana Bott, 1969a (two species), and added two new species: Fredilocarcinus apyratii Magalhães and Türkay, 1996c, from the southwestern Brazilian Amazon, and Goyazana rotundicauda Magalhães and Türkay, 1996c, from the western Amazon region in Brazil, Peru and Ecuador. These were the last taxa to be described for the family in the last 20 years and this long period could suggest that the "discovery" phase for the family might be ending (Yeo et al., 2008; Magalhães et al., 2016).

This series of papers on the Trichodactylidae was resumed with the revisions of Dilocarcinus $\mathrm{H}$. Milne 
Edwards, 1853 (three species) and Poppiana Bott, 1969a (three species) (Magalhães and Türkay, 2008a), and Bottiella Magalhães and Türkay, 1996a (three species) and Rotundovaldivia Pretzmann, 1968c (one species) (Magalhães and Türkay, 2008b), published after a long interval of 12 years. Before too long, the revision of the Mexican trichodactyline species belonging to two genera, Avotrichodactylus Pretzmann, 1968c (two species) and Rodriguezia Bott, 1969a (two species), also appeared (Magalhães and Türkay, 2012). Despite the fact that no new species were introduced in those studies, synonyms were proposed on the basis of a large amount of material examined for most species, which also allowed a better understanding of their distribution. In addition, lectotype designations were done for Poppiana argentiniana (Rathbun, 1905), and Poppiana dentata (Randall, 1840).

The revision of three genera is still unfinished. The manuscript on Moreirocarcinus Magalhães and Türkay, 1996a, and Valdivia White, 1847, was in preparation at the time of Michael's death and will be published posthumously in this tribute series. Then, the revision of Trichodactylus Latreille, 1828, s. str. should follow. This genus was established by Latreille (1828) to accommodate Trichodactylus fluviatilis Latreille, 1828 (“... apporté du Brésil, où elle fréquente les eaux douces”, according to Latreille, 1828), and currently includes 11 species (Magalhães and Türkay, 1996a). The type species, T. fluviatilis, has a wide distribution along the river systems of the eastern coastal strip of Brazil from the states of Pernambuco to Rio Grande do Sul, as well as the upper Paraná River basin (Magalhães, 2003). This species, however, appears to be highly variable in carapace morphology, but remains rather conservative in terms of the male first gonopod. The large amount of material collected, however, has raised several taxonomic, nomenclatural and zoogeographical issues (Melo, 1967; Magalhães and Türkay, 1996a; Almeida et al., 2008), which will need to be resolved. Adding to these problems, such challenges are also present in Trichodactylus crassus A. Milne-Edwards, 1869, Trichodactylus dentatus H. Milne Edwards, 1853, and Trichodactylus petropolitanus (Göldi, 1886), other currently recognized congeners that are partially sympatric, which quite often make the delimitation of those taxa very difficult. This scenario is further aggravated by the fact that most of the type material is old, dry, damaged, missing, and/or with inaccurate geographical information. Due to all these reasons, we chose to leave the revision of this genus for the end of the series, seeking more and better material and accumulated evidence to address these issues more completely. With the development of increasingly sensitive genetic techniques for systematic studies, it became clear to us that this would be the best way to move forward and, thus we have extended our partnership to include the Laboratory of Bioecology and Crustacean Systematics, University of São Paulo (Ribeirão Preto, Brazil), led by Dr. Fernando L. Mantelatto, and the laboratory of Dr. Sebastian Klaus at the Department of Ecology and Evolution of the Goethe-University - Biologicum, Frankfurt am Main. Some studies on the genus are currently in preparation.

\section{REMINISCENCES AND IMPRESSIONS}

My professional and personal relationship with Michael began just four days before Christmas in December 1984. In mid-November that year, I had just received my Master's degree based on a thesis about the larval development of the shrimp Macrobrachium amazonicum (Heller, 1862), working at the Instituto Nacional de Pesquisas da Amazônia (Manaus, Brazil). With the assistance of my thesis supervisor, Prof. Dr. Wolfgang J.Junk, then leader of the Working Group for Tropical Ecology of the Max-Plank-Institute for Limnology (Plön, Germany), I was awarded a travel grant from the Max-Planck Society to further study the taxonomy of the Amazonian freshwater decapods. The visit was to be to Leiden (the Netherlands), hosted by Prof. Dr. Lipke B. Holthuis for one month, and followed by a stay of two months in Frankfurt, hosted by Michael. I was already familiar with Holthuis' work, as he published many papers in English, but I had never heard much about Michael's work and could not find much about the man or his work given the pre-digital world we lived in. Therefore, I was a bit afraid of how I would be hosted and if I could indeed further my education about the systematics of Neotropical freshwater crabs. At the time I was completely ignorant about the group, as almost all relevant literature was in German, a language that I could not read and any efforts to understand the group using Richard Bott's and Gerhard Pretzmann's papers were unsuccessful.

Therefore, I had no option but to trust Dr. Junk's word and tried to gather as much material as possible 

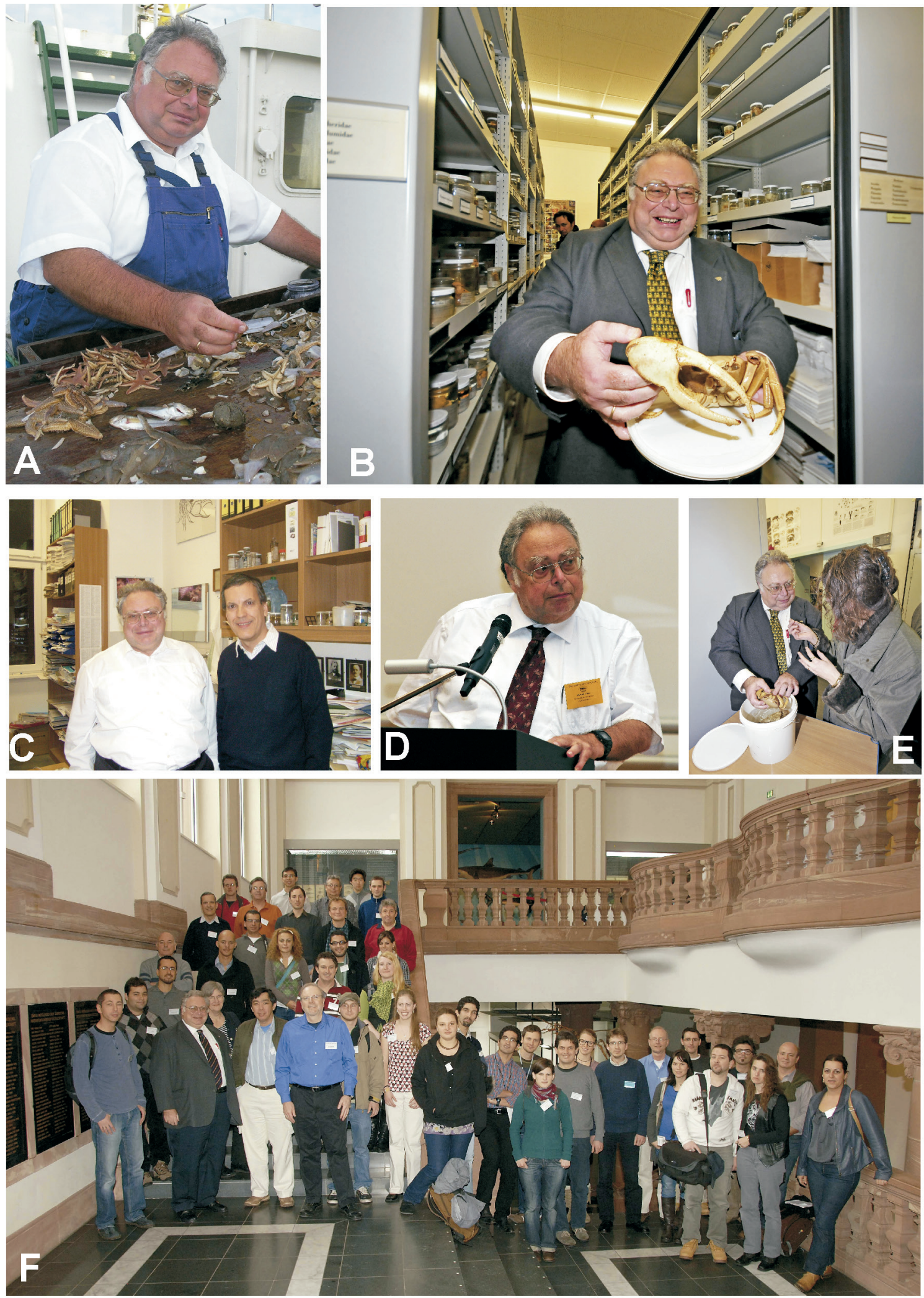

Figure 2. Michael Türkay, at different times of his professional life. A, sorting specimens on board of the RV Senckenberg, at the Dogger Bank, North Sea, 10 August 2008; B, in the crustacean collection of the Senckenberg Natural History Museum, 10 December 2010; C, with the author at his office, 16 February 2007; D, hosting the $8^{\text {th }}$ International Crustacean Congress in Frankfurt am Main, 20 August 2014; E, in the crustacean collection of the Senckenberg Natural History Museum, 10 December 2010; F, hosting the $21^{\text {st }}$ International Senckenberg Conference on Biology of Freshwater Decapods, Frankfurt am Main, 9 December 2010 (front row, second from the left). Photos: M. Sonnewald (A); O. Mengedoht (B, D-F); K. Sakai (C). 
of the group from Brazil to take with me to Europe for further study. In this regard, I must emphasize the valuable assistance received from Prof. Dr. Gustavo Augusto Schmidt de Melo, then curator of Crustacea at the Museu de Zoologia, Universidade de São Paulo, who without knowing anything about me, nevertheless loaned me all their lots of Brazilian freshwater crabs, the largest collection among Neotropical institutions. This turned out to be a huge collection, so vast that I had to leave most of it in Brazil and select lots to take to Europe to work with Lipke and Michael.

My fears about Michael were totally unwarranted. His friendly and co-operative nature made me feel at once very much welcome at the Senckenberg Museum and even in his home. It was Christmas Eve and he invited me to spend my very first White Christmas Night with his family and, later on, showed me around Frankfurt. He was truly passionate about his home town, always remarking on its international character. A natural teacher, Michael quickly taught me the basics of Neotropical freshwater crabs and guided me through my first steps in the study of the group. Those two months with Michael were so enlightening and productive that we agreed I should extend my stay for at least another half month and I changed my return ticket to include brief visits to other European collections to see the type material of some species in order to answer some issues raised after examining the material I had brought with me.

The most important outcomes of that first contact were both professional and personal. Scientifically, besides the description of the first pseudothelphusid crab from the southern tributaries of the Amazon River (Magalhães and Türkay, 1986), the important decision was made to embark on a revision of the Trichodactylidae. The systematics of the family was quite confusing (see above) and solving most of the problems required examining type material and gathering good collections from Brazil, as this group has its highest diversity in this country (Cumberlidge et al., 2014; Magalhães et al., 2016). One of the most compelling factors for this revision was the discovery of male specimens of Sylviocarcinus devillei $\mathrm{H}$. Milne Edwards, 1853, which would imply a relevant change in the systematics of the family (Magalhães and Türkay, 1996a). In spite of the good series of specimens we could count on, there were still too many taxonomic and nomenclatural issues that defied an easy study, and we could not move forward as much as we would like. Michael also suggested that I use this study as the theme for my doctoral dissertation and, meanwhile, try to get more material of some problematic species. From a personal point of view, this first meeting established a lifelong friendship, certainly the best outcome of the visit. Michael was always very kind and helpful with my questions and demands. The initial fears soon turned to admiration as Michael patiently guided me through my first steps in the study of the Neotropical freshwater crabs and showed me the best practices for a good taxonomic work. He was truly inspiring to me. Even long after that first visit, I still considered him as a mentor.

Michael's very good memory, his outstanding knowledge of the history of Carcinology, and the intimate knowledge he had of his working environment, bewildering it may have been to all visitors were excellent resources to our study. On the several occasions I visited him, only once did I not found his desk completely full with piles of documents, reprints, books and even vials with specimens. However, he somehow managed always to find what he was looking for among that apparent mess, or pulled out the right reference for some information we needed, even very old literature. Particularly useful for my understanding of the taxonomic status of the Trichodactylidae was his knowledge about some behind-the-scenes facts regarding the animosity between $\mathrm{R}$. Bott and G. Pretzmann, which had contributed to the taxonomic problems in the family.

I returned to Frankfurt in September 1988 for a nearly five-month long visit to continue the studies initiated in 1987 at the University of São Paulo for my doctoral degree under the supervision of Prof. Dr. Gustavo A. S. de Melo. Following the plan outlined during the first visit, and taking his advice, I bought a three-month Eurorailpass. From Frankfurt, conveniently located in Central Europe, I visited all museums and institution holding material of trichodactylid crabs and examined the type material of all nominal species described for the group (I had already done that for the North American museums earlier that year). His instructions for my visit to the Museum für Naturkunde, Humboldt-Universität zu Berlin, at that time situated in East Berlin were 
particularly curious. He told me that I would be asked to exchange some amount of Westdeutsche Mark for Eastern ones (being worth nearly nothing compared to the currency of West Germany), that I would not be able to spend all of them, and not be allowed to exchange them back neither. He guided me to hand over the sum to Dr. H.-E. Gruner, my host, who in turn would send Michael some good books on Biology and Zoology edited in East Germany; Michael, of course, would reimburse me in Westdeutsche Marks. Furthermore, he suggested that I buy a few bottles of correction fluid as a gift for our colleagues, a resource not easily available in East Germany at the time.

Michael was also concerned about how Dr. G. Pretzmann would receive the news that a new taxonomic study of the Trichodactylidae was underway in the Senckenberg Museum. Therefore, he considered the possibility that I avoided visiting the Vienna Museum of Natural History or, if inevitable, leaves it to the end of my stay in Europe. He was concerned that Dr. Pretzmann could rush and try to publish something in advance of our study. The visit, however, was inevitable because many types of Pretzmann's nominal species are deposited there and the types of several species he had borrowed from other museums were still being kept there. During my previous visits to other European institutions, after knowing that I was considering going to Vienna, some curators gave me letters to hand directly to Dr. Pretzmann requesting the immediate return of their long overdue loans. Again, my fears of what Dr. Pretzmann would do proved unjustified. Although the visit has been announced with just a short notice in early December 1988, I was still warmly welcomed by Dr. Pretzmann, who promptly opened the collections to me and kindly helped to find the specimens (I must say that the collection was not very well organized and some detective work had to be done in order to find some types). Nonetheless, the visit was quite successful and greatly contributed to clear several taxonomic issues we had about the trichodactylids, thus allowing us to propose a new generic system for the Trichodactylidae (Magalhães and Türkay, 1996a) during the last part of my period in Frankfurt.

That December 1988 also marked my second Christmas in Germany and again, I spent it in the comforting warmth of the Michael's family home. During the visit, I stayed in a comfortable room of the Senckenberg Museum's guesthouse. However, the museum closed for the holidays and Michael invited me to stay for the whole period between Christmas and the New Year at his home. He had a small office in the attic equipped with a small stereoscope (where a bed was provided for my stay). Those were very nice days despite the cold weather outside: most of the day we worked on the crabs, but Michael also took me for short walks in the nice neighborhood where he lived at that time (in Dreieichenhain, a town just south of Frankfurt). Michael's multiple interests made him a polymath as he could keep long and consistent conversations on various subjects, not only restricted to carcinology but extending to many other scholarly aspects of biological sciences, politics, history and the most varied topics. It was particularly enjoyable for me chatting with him and Mrs. Türkay during lunchtimes and in the evenings, sipping a good German wine. I was enthralled with his explanations about food, beverages, the history of Germany, and stories about his maritime expeditions. These pleasant moments were frequent when I visited him, because I was always invited to his home, a local restaurant or even to have a Frankfurter Würstchen with bread and mustard at the weekly market that usually happens on Thursdays in the Bockenheimer Warte square near the museum.

I left Frankfurt in mid-January 1989, with my doctoral dissertation well structured, and with a plan to publish our revision, not as a monograph, but as a series of papers in Senckenbergiana biologica, as soon as we had enough data to complete a good taxonomic treatment for each of the trichodactylid genera. After the last publication, we had hoped that all the reprints could be bound together and used like a monograph.

The original idea foresaw the first publication appearing soon after I finished my doctorate. However, we only had another opportunity to meet again when I went to Frankfurt to attend the International Senckenberg-Symposium on Crustacea Decapoda, held from 18-22 October 1993. We agreed that I would stay for a couple of weeks longer to advance the preparation of the planned manuscripts. It may also be worth mentioning an issue that we had at that moment. Rodríguez (1992) had recently published the second part of his monographic work on the freshwater crabs of America, this time the revision of the Trichodactylidae. Another aspect of Michael's character, the scientific 
and intellectual honesty, was then highlighted. He told me in confidence that he has been one of the referees for that monograph and made several comments to contribute to the work of Dr. G. Rodríguez. Much of those comments came from our own data regarding issues that Dr. Rodríguez could not evaluate because, as already mentioned, he did not have the extensive amount of material from Brazil nor examined the types of many nominal species, particularly those being on loan to Dr. Pretzmann in Vienna. I believe that his careful action contributed to the fact that the systems by G. Rodríguez and ours are quite similar.

We tried to get our first three papers on the trichodactylids (Magalhães and Türkay, 1996a; 1996b; 1996c) ready for publication soon after the 1993 visit, but the main reason for delaying to 1996 was the rather overwhelming administrative and bureaucratic tasks that we both were committed to in our respective institution. This situation got worse in the years ahead and ended up invalidating the original idea in a way that we could never finish our revision as planned. I could only arrange for other visits in early 2003, early 2007, and in the spring of 2008, when finally the next set of papers on this revision were completed (Magalhães and Türkay, 2008a; 2008b). These articles were included in the very last issue of Senckenbergiana biologica (the journal was closed in December 2008). After more visits in early and late 2010 one more paper was finished (Magalhães and Türkay, 2012); some timely articles on pseudothelphusid crabs had also appeared in the meantime. To resume and advance the preparation of the manuscript on the genera Moreirocarcinus and Valdivia, the penultimate article of the series, was the main goals of my next stay in Frankfurt, in mid April 2015. The manuscript has now been completed and shall be published soon in this very series.

Our scientific partnership, in spite some of the difficulties mentioned above, was one of his most fruitful. We co-authored 11 papers, second only to his partnership with Dr. K. Sakai, with whom he has co-authored 19 papers (see publications listed in Sonnewald and Apel, 2016a; 2016b).

As an undergraduate student, when we were preparing our first paper, I told him that he should be the first author since he had done most of the intellectual work. His generosity, another feature of his character, then became evident. His reply (to the best of my recollection) was "This is a momentaneous occasion in your training. You should be the first author because you raised the main question, you are the expert from the region, and you should become known as that". Another aspect of his generosity was that he was always receptive to my proposals for exchanging specimens, as long as it was possible. Over the years, this mutual exchange helped the Seckenberg Museum to build up a good collection of freshwater decapods from Brazil, and equally contributed to the Instituto Nacional de Pesquisas da Amazônia (INPA) to gather a relatively small, but very representative collection of the diversity of Neotropical freshwater crabs. He uses to say that keeping the door open to co-operative work and such exchanges was one of the main factors in increasing the collection, but also to strengthen his institution. I told him once that I consider Frankfurt to be my home town in Europe because, after so many visits, I felt a bit as a member of the Crustacean Section because Michael has always made me feel at home there (in one shelf there was a space with my name in it, where he kept any Neotropical freshwater decapods received during the intervals between my visits).

The sad news that my dear friend had passed away so suddenly was very painful to me, not only because we had met just a few months ago. Even then, he did not disclose the seriousness of his illness and he was still very enthusiastic about being able to dedicate much more of his time to scientific work after his retirement, as well as discussing our ongoing work. He even had plans to increase our scientific partnership.

In conclusion, I will always remember Michael Türkay as a true friend and an excellent scientist, with admiration, respect and affection. He was an outstanding man who inspired friends and associates, both by the life he lead and the science he pursued.

It is a pleasure for the Brazilian Crustacean Society and for me in particular, to dedicate this article and this series of papers in Nauplius as a lasting tribute to Michael.

\section{ACKNOWLEDGEMENTS}

Moritz Sonnewald offered invaluable help in providing information about Michael's publications, PDF copies of some, and insights. Moritz Sonnewald and Oliver Mengedoht kindly provided the photos of Michael that illustrate this article. Ingo Wehrtmann, Néstor Campos 
and Marcos Tavares also contributed with further PDF's. Ludwig Buckup kindly offered testimony about his relationship with Michael (of which I only mention that related to Aegla). Sammy De Grave, Peter Ng and Marcos S. Tavares also made corrections and useful suggestions that greatly improved the manuscript; Sammy additionally edited it for the English. I am very much grateful for the help of all these colleagues. I would like to renew my thanks to the persons and funding agencies that have made the partnership between me and Michael possible over all these years (in Brazil: Gustavo Augusto Schmidt de Melo; CNPq - Conselho Nacional de Desenvolvimento Científico e Tecnológico - CNPq; CAPES - Coordenação de Aperfeiçoamento de Pessoal de Nível Superior; INPA/PCI, Programa de Capacitação Institucional do Instituto Nacional de Pesquisas da Amazônia; in Germany: Wolfgang Johannes Junk; Max-Planck-Gesellschaft; DAAD Deutscher Akademischer Austauschdienst). I also thank CNPq for an ongoing research Grant (proc. nr 304736/2015-5).

\section{RefERENCES}

Almeida, A.O.; Coelho, P.A.; Luz, J.R.; Santos, J.T.A. and Ferraz, N.R. 2008. Decapod crustaceans in fresh waters of southeastern Bahia, Brazil. Revista de Biología Tropical, 56(3): 1225-1254.

Bentes, A.B.; Lima, W.G.; Fernandes, S.; Paula, J.D.; Silva, K.; Abrunhosa, F. and Bentes, B. 2013. Occurrence of Charybdis hellerii (Milne Edwards, 1867) (Crustacea, Decapoda, Portunidae) in an Amazonian estuary. Biota Amazonica, 3(3): 181-184.

Bond-Buckup, G. and Buckup, L. 1994. A família Aeglidae (Crustacea, Decapoda, Anomura). Arquivos de Zoologia, 32(4): 159-346.

Bott, R. 1969a. Die Süsswasserkrabben Süd-Amerikas und ihre Stammesgeschichte. Eine Revision der Trichodactylidae und der Pseudothelphusidae östlich der Anden (Crustacea, Decapoda). Abhandlungen der Senckenbergischen Naturforschenden Gesellschaft, 518: 1-94.

Bott, R. 1969b. Präadaption, Evolution und Besiedlungsgeschichte der Süsswasserkrabben der Erde. Natur und Museum, 99(6): 266-275.

${ }^{* *}$ Campos, N.H. and Türkay, M. 1989. On a record of Charybdis helleri from the Caribbean coast of Colombia (Crustacea: Decapoda: Portunidae). Senckenbergiana maritima, 20(3/4): 119-123.

Collins, P.A.; Giri, F. and Williner, V. 2009. Range extension for three species of South American freshwater crabs (Crustacea: Decapoda: Trichodactylidae). Zootaxa, 1977: 49-54.

Cumberlidge, N.; Álvarez, F. \& Villalobos, J.L. 2014. Results of the global conservation assessment of the freshwater crabs
(Brachyura, Pseudothelphusidae and Trichodactylidae): The Neotropical region, with an update on diversity. Zookeys, 457: $133-157$.

Cumberlidge, N. and Ng, P.K.L. 2009. Systematics, evolution, and biogeography of freshwater crabs. p. 491-508. In: J.W. Martin; K.A. Crandall, and D.L. Felder (eds), Decapod Crustacean Phylogenetics. Crustacean Issues, Vol. 18. S. Koenemann (series ed.) Boca Raton, London, New York: CRC Press, Taylor \& Francis Group.

Dana, J.D. 1851. Conspectus Crustaceorum quæ in Orbis Terrarum circumnavigatione, Carolo Wilkes e Classe Reipublicæ Fœderatæ Duce, lexit et descripsit. Proceedings of the Academy of Natural Sciences of Philadelphia, 5: 247-254, 267-272.

De Grave, S.; Pentcheff, N.D.; Ahyong, S.T.; Chan, T.-Y.; Crandall, K.A.; Dworschak, P.C.; Felder, D.L.; Feldmann, R.M.; Fransen, C.H.J.M.; Goulding, L.Y.D.; Lemaitre, R.; Low, M.E.Y.; Martin, J.W.; Ng, P.K.L.; Schweitzer, C.E.; Tan, S.H.; Tshudy, D. and Wetzer, R. 2009. A classification of living and fossil genera of decapod crustaceans. The Raffles Bulletin of Zoology, Suppl. 21: 1-109.

Dworschak, P.C. 2014. Gerhard Pretzmann (1929-2013): his contributions to carcinology. Crustaceana, 87(14): 17041723.

Fabricius, J.C. 1787. Mantissa Insectorum sustens eorum Species nuper detectas adjectis Characteribus genericis, Differentiis specificis, Emendationibus, Obervationibus 1: i-xx, 1-348. Hafniae.

Felder, D.L. and Dworschak, P.C. 2015. Comments on two questionably new axiidean taxa from the Gulf of Mexico (Crustacea: Decapoda). Zootaxa, 4057(2): 265-272.

Göldi, E.A. 1886. Studien über neue und weniger bekannte Podophthalmen Brasiliens. Archiv für Naturgeschichte, 52(1): 19-46.

Haan, W. de. 1833-1850. Crustacea. In: P.F. von Siebold (ed), Fauna Japonica sive Descriptio Animalium, Quae in Itinere per Japoniam, Jussu et Auspiciis Superiorum, qui Summum in India Batava Imperium Tenent, Suscepto, Annis 18231830 Collegit, Noitis, Observationibus et Adumbrationibus Illustravit. Leiden, Lugduni-Batavorum. Pp. i-xvii, i-xxxi, ix-xvi, 1-243, pls. A-J, L-Q 1-55, circ. Table 2.

Heller, C. 1862. Beiträge zur näheren Kenntniss der Macrouren. Sitzungsberichte der Mathematisch-Naturwissenschaftlichen Klasse der Kaiserlichen Akademie der Wissenschaften, Wien, 45(1): 389-426, pls. 1-2.

Kensley, B. and Heard, R. 1990. The genus Axianassa (Crustacea, Decapoda, Thalassinidea) in the Americas. Proceedings of the Biological Society of Washington, 103(3): 558-572.

Latreille, P.A. 1828. Trychodactyle, Trichodactylus. In: Encyclopédie Méthodique Histoire naturelle, Entomologie, ou Histoire Naturelle des Crustacés, des Arachnides et des Insectes 10: 705. Paris.

Lemaitre, R. 1995. Charybdis hellerii (Milne Edwards, 1867), a nonindigenous portunid crab (Crustacea: Decapoda: Brachyura) discovered in the Indian River lagoon system of Florida. Proceedings of the Biological Society of Washington, 108(4): 643-648.

Magalhães, C. 2003. Brachyura: Pseudothelphusidae e Trichodactylidae. p. 143-297. In: G.A.S. Melo (ed), Manual 
de Identificação dos Crustáceos Decápodos de Água Doce Brasileiros. São Paulo, Edições Loyola.

Magalhães, C.; Campos, M.R.; Collins, P.A. and Mantelatto, F.L. 2016. Diversity, distribution and conservation of freshwater crabs and shrimps in South America. In: T. Kawai and N. Cumberlidge (eds), A global overview of the conservation of freshwater decapod crustaceans. Chapter 11. Springer Verlag (in press).

**Magalhães, C.; Campos, M.R. and Türkay, M. 2013. Freshwater crabs from eastern Panamá: a new species of Potamocarcinus H. Milne Edwards, 1853, and new records of two littleknown species (Crustacea: Decapoda: Pseudothelphusidae, Trichodactylidae). Zootaxa, 3702(4): 348-356.

**Magalhães, C. and Türkay, M. 1986. Brasiliothelphusa, a new Brazilian freshwater-crab genus (Crustacea: Decapoda: Pseudothelphusidae). Senckenbergiana biologica, 66: 371-376.

** Magalhães, C. and Türkay, M. 1996a. Taxonomy of the neotropical freshwater crab family Trichodactylidae. I. The generic system with description of some new genera (Crustacea: Decapoda: Brachyura). Senckenbergiana biologica, 75(1/2): 63-95.

**Magalhães, C. and Türkay, M. 1996b. Taxonomy of the neotropical freshwater crab family Trichodactylidae. II. The genera Forsteria, Melocarcinus, Sylviocarcinus, and Zilchiopsis (Crustacea: Decapoda: Brachyura). Senckenbergiana biologica, 75(1/2): 97-130.

** Magalhães, C. and Türkay, M. 1996c. Taxonomy of the neotropical freshwater crab family Trichodactylidae. III. The genera Fredilocarcinus and Goyazana (Crustacea: Decapoda: Brachyura). Senckenbergiana biologica, 75(1/2): 131-142.

** Magalhães, C. and Türkay, M. 2008a. Taxonomy of the neotropical freshwater crab family Trichodactylidae, IV. The genera Dilocarcinus and Poppiana (Crustacea, Decapoda, Trichodactylidae). Senckenbergiana biologica, 88(2): 185-215.

** Magalhães, C. and Türkay, M. 2008b. Taxonomy of the neotropical freshwater crab family Trichodactylidae, V. The genera Bottiella and Rotundovaldivia (Crustacea, Decapoda, Trichodactylidae). Senckenbergiana biologica, 88(2): 217-230.

** Magalhães, C. and Türkay, M. 2008c. A new species of Kingsleya from the Yanomami Indians area in the upper Rio Orinoco, Venezuela (Crustacea, Decapoda, Brachyura, Pseudothelphusidae). Senckenbergiana biologica, 88(2): 231-237.

**Magalhães, C. and Türkay, M. 2010. A new freshwater crab of the genus Brasiliothelphusa Magalhães and Türkay, 1986 from Rio Aripuanã, southern Amazon region, Brazil (Decapoda: Pseudothelphusidae). Nauplius, 18(2): 103-108.

** Magalhães, C. and Türkay, M.2012. Taxonomy of the neotropical freshwater crab family Trichodactylidae. VI. The genera Avotrichodactylus and Rodriguezia (Decapoda: Brachyura: Trichodactylidae). Nauplius, 20(1): 27-40.

** Magalhães, C.; Türkay M. and Means, D.B. 2009. The status of Kunziana Pretzmann, 1971 (Crustacea: Decapoda: Pseudothelphusidae), with a redescription of the holotype of $K$. irengis Pretzmann, 1971. Zootaxa, 2276: 40-48.

Mantelatto, F.L.M. and Dias, L.L.1999. Extension of the known distribution of Charybdis hellerii (A. Milne-Edwards, 1867) (Decapoda, Portunidae) along the western tropical South Atlantic. Crustaceana, 72(6): 617-620.
Melo, G.A.S. 1967. Diferenciação geográfica e dimorfismo sexual de Trichodactylus (Trichodactylus) fluviatilis Latreille, 1825 (Crustacea, Brachyura). Papéis Avulsos de Zoologia, 20(3): 13-44.

Milne-Edwards, A. 1867. Descriptions de quelques espéces nouvelles de Crustacés Brachyures. Annales de la Société entomologique de France, 4e série, 7: 263-288.

Milne-Edwards, A. 1869. Révision des genres Trichodactylus, Sylviocarcinus et Dilocarcinus et description de quelques espèces nouvelles qui s'y rattachent. Annales de la Société entomologique de France, 4e série, 9: 170-178.

Milne-Edwards, A. 1880. Reports on the results of dredging, under the supervision of Alexander Agassiz, in the Gulf of Mexico, and in the Caribbean Sea, 1877,'78, '79, by the United States Coast Survey Steamer "Blake," Lieut.-Commander C.D. Sigsbee, U.S.N., and Commander J.R. Bartlett, U.S.N., commanding. VIII. Études préliminaires sur les Crustacés. Bulletin of the Museum of Comparative Zoology at Harvard College, 8(1): 1-68, pls. 1, 2.

Milne Edwards, H. 1853. Mémoire sur la famille des Ocypodiens. Suite (1). Deuxiéme Tribu Principale. Annales des Sciences Naturelles, 3e série, 20: 163-228, pls 6-11.

Milne Edwards, H. \& Lucas, H. 1842-1844. Crustacés. In: A. d'Orbigny, Voyage dans l'Amérique méridionale (le Brésil, la République orientale de l'Uruguay, la République Argentine, la Patagonie, la République du Chili, la République de Bolivia, la République du Pérou), exécuté pendant les Années 18261833, 6(1): 1-39, + Atlas, pls 1-17. Strasbourg.

Ng, P.K.L., Guinot, D. and Davie, P.J.F. 2008. Systema Brachyurorum: Part I. An annotated checklist of extant brachyuran crabs of the world. The Raffles Bulletin of Zoology, Supplement 17: 1-286.

Pedraza, M; Magalhães, C. and Tavares, M. 2015. Morfología comparada del esqueleto axial en la familia de cangrejos de agua dulce Trichodactylidae (Crustacea: Decapoda: Brachyura). Papéis Avulsos de Zoologia, 55(7): 103-114.

Pretzmann, G. 1965. Vorläufiger Bericht über die Familie Pseudothelphusidae. Anzeiger der mathematischnaturwissenschaftlichen Klasse der Österreichischen Akademie der Wissenschaften, 1965(1): 1-10.

Pretzmann, G. 1968a. Weitere neue südamerikanische Süßwasserkrabben (Vorläufige Mitteilung). Entomologisches Nachrichtenblatt, 15(Sonderheft 2): 1-6.

Pretzmann, G. 1968b. Mexicanische Süsswasserkrabben der Gattung Pseudothelphusa (Vorläufige Mitteilung). Entomologisches Nachrichtenblatt, 15(Sonderheft 2): 6-8.

Pretzmann, G. 1968c. Die Familie Trichodactylidae (Milne Edwards, 1853) Smith. (Vorläufige Mitteilung) Entomologisches Nachrichtenblatt, 15(Sonderheft 7-8): 70-76.

Pretzmann, G. 1971a. Eine interessante Süsswasserkrabbe aus Britisch Guayana. Anzeiger der mathematischnaturwissenschaftlichen Klasse der Österreichischen Akademie der Wissenschaften, 3(1-2): 46-48.

Pretzmann, G. 1971b. Fortschritte in der Klassifizierung der Pseudothelphusidae. Sitzungsberichte der mathematischnaturwissenschaftlichen Klasse der Österreichischen Akademie der Wissenschaften, 179(8): 15-24.

Pretzmann, G. 1972. Die Pseudothelphusidae (Crustacea Brachyura). Zoologica, 120: 1-184. 
Pretzmann, G. 1973. Grundlagen und Ergebnisse der Systematik der Pseudothelphusidae. Zeitschrift für zoologische Systematik und Evolutionforschung, 11(3): 196-218.

Pretzmann, G. 1978. Neue Süsswasserkrabben aus den Anden. Sitzungsberichte der Österreichischen Akademie der Wissenschaften, mathematisch-naturwissenschaftliche Klasse Abt. I, 187(2): 163-170.

Randall, J.W. 1840. Catalogue of the Crustacea brought by Thomas Nuttall and J. K. Townsend, from the west coast of North America and the Sandwich Islands, with descriptions of such species as are apparently new, among which are included several species of different localities, previously existing in the collection of the Academy. Journal of the Academy of Natural Sciences of Philadelphia, 8(1): 106-147, pls 3-7.

Rathbun, M.J. 1893. Descriptions of new species of American fresh-water crabs. Proceedings of the United States National Museum, 16(959): 649-661, pl. 73-77.

Rathbun, M.J. 1897. Descriptions de nouvelles especes de crabes d'eau douce appartenant aux collections du Muséum d'Histoire naturelle du Paris. Bulletin du Muséum Nationale d'Histoire Naturelle, Paris, 3: 58-61.

Rathbun, M.J. 1905. Les crabes d'eau douce. Nouvelles Archives du Muséum d'Histoire naturelle, Paris, 7(4), 159-321, text-figs. 38-105, volume pls. 13-22. [pls. XI-X for Rathbun's article]

Rathbun, M.J. 1918. The grapsoid crabs of America. Bulletin of the United States National Museum, 97: 1-461, pls. 1-161.

Rocha, S.S. and Bueno, S.L.S. 2004. Crustáceos decápodes de água doce com ocorrência no Vale do Ribeira de Iguape e rios costeiros adjacentes, São Paulo, Brasil. Revista Brasileira de Zoologia, 21(4): 1001-1010.

Rodriguez, G. 1982. Les crabes d'eau douce d'Amerique. Famille des Pseudothelphusidae. Paris, Editions ORSTOM, 224p. (Collection Faune Tropicale 22)

Rodríguez. G. 1992. The Freshwater Crabs of America. Family Trichodactylidae and Supplement to the Family Pseudothelphusidae. Paris, Editions ORSTOM, 189p. (Collection Faune Tropicale 31)

Rodríguez, G. and Smalley, A.E. 1972. Los cangrejos de agua dulce de México de la familia Pseudothelphusidae (Crustacea, Brachyura). Anales del Instituto de Ciencias del Mary Limnología, Universidad Nacional Autónoma de México, 40(1): 69-112, pls 1-12. [1969]

**Rodriguez, G. and Türkay, M. 1978. Der generische Status einiger kolumbianischer Süßwasserkrabben mit Beschreibung einer neuen Art, Neostrengeria botti n.sp. (Crustacea: Decapoda: Pseudothelphusidae). Senckenbergiana biologica, 59: 297-306.

Rosa, L.C. 2014. New records of portunid crabs (Decapoda: Brachyura: Portunidae) from Sergipe, NE Brazil. Check List, 10(2): 445-447.

*Sakai, K. and Türkay, M. 1977. Die Gattung Ocypode in der Sammlung des Genfer Naturhistorischen Museums (Crustacea: Decapoda). Revue Suisse de Zoologie, 84(1): 177-180.

*Sakai, K. and Türkay, M. 2012. A collection of Thalassinidea Latreille, 1831 (Decapoda, Pleocyemata) from the Senckenberg Forschungsinstitut and Natural History Museum, Frankfurt am Main. Crustaceana, 85(6): 723-765.

*Sakai, K. and Türkay, M. 2013. Revision of the genus Ocypode with the description of a new genus, Hoplocypode (Crustacea:
Decapoda: Brachyura). Memoirs of the Queensland MuseumNature, 56(2): 665-793.

*Sakai, K. and Türkay, M. 2014. A Review of the collections of the infraorders Thalassinidea Latreille, 1831 and Callianassidea Dana, 1852 (Decapoda, Pleocyemata) lodged in three German museums, with revised keys to the genera and species. Crustaceana, 87(2): 129-211.

*Sakai, K.; Türkay, M. and Yang, S.-L. 2006. Revision of the Helice/ Chasmagnathus complex (Crustacea: Decapoda: Brachyura). Abhandlungen der Senckenbergischen Naturforschenden Gesellschaft, 565: 1-77.

Say, T. 1818. An account of the Crustacea of the United States [part 5]. Journal of the Academy of Natural Sciences of Philadelphia, 1: 235-253.

**Schubart, C.D., Reimer, J.; Diesel, R. and Türkay, M. 1997. Taxonomy and ecology of two endemic freshwater crabs from western Jamaica with the description of a new Sesarma species (Brachyura: Grapsidae: Sesarminae). Journal of Natural History, 31(3): 403-419.

Schmitt, W.L. 1924. The macruran, anomuran and stomatopod Crustacea. Bijdragen tot de kennis der fauna von Curaçao. Resultaten eener reis van Dr.C.J. Van der Horst in 1920. Bijdrage tot de Dierkunde, 23: 9-82.

Smalley, A. 1970. A new genus of freshwater crabs from Guatemala, with a key to the Middle American genera (Crustacea, Decapoda, Pseudothelphusidae). American Midland Naturalist, 83(1): 96-106.

Sonnewald, M. and Apel, M. 2016a. In rememberance of Michael Türkay (3 April 1948 - 9 September 2015), a tower of strength in the world of crustaceans. Journal of Crustacean Biology, 36(1): 106-117.

Sonnewald, M. and Apel, M. 2016b. Corrigendum to: In rememberance of Michael Türkay (3 April 1948 - 9 September 2015), a tower of strength in the world of crustaceans. (doi:10.1163/1937240X-00002400) (Journal of Crustacean Biology, 36: 106-117 (2016)). Journal of Crustacean Biology, 36(2): 265.

Spivak, E. 2010. The crab Neohelice (=Chasmagnathus) granulata: an emergent animal model from emergent countries. Helgoland Marine Research, 64(3): 149-154.

Stimpson, W. 1860. Notes on North American Crustacea. No. II. Annals of the Lyceum of Natural History of New-York, 7: 176-246, pls. 2, 5.

Tavares, M. 2011. Alien decapod crustaceans in the southwestern Atlantic Ocean. p. 251-267. In: B. Galil, P.F. Clark and J.T. Carlton (eds), In the Wrong Place - Alien Marine Crustaceans: Distribution, Biology and Impacts. Dordrecht, Springer.

**Türkay, M. 1967. Neue Brachyuren von der Westküste Südamerikas (Crustacea, Decapoda). Senckenbergiana biologica, 48(5/6): 361-364.

**Türkay, M. 1968. Dekapoden von den Margarita-Inseln (Venezuela), (Crustacea). Senckenbergiana biologica, 49(3/4): 249-257.

**Türkay, M. 1970. Die Gecarcinidae Amerikas. Mit einem Anhang über Ucides Rathbun (Crustacea: Decapoda). Senckenbergiana biologica, 51(5/6): 333-354.

*Türkay, M. 1971a. Die Corystidae und Atelecyclidae des Naturhistorischen Museums Genf (Crustacea, Decapoda). Revue Suisse de Zoologia, 78(1): 227-230. 
*Türkay, M. 1971b. Die Portunidae des naturhistorischen Museums Genf, mit einem Anhang über die Typen von Ovalipes ocellatus floridanus Hay \& Shore 1918 (Crustacea, Decapoda). Archives des Sciences, Genève, 24: 111-143, figs. 1-3, pls.1-6.

**Türkay, M. 1972. Neue Höhlendekapoden aus Brasilien (Crustacea). Revue suisse de Zoologie, 79(1): 415-418.

Türkay, M. 1973a. Die Gecarcinidae Afrikas (Crustacea: Decapoda). Senckenbergiana biologica, 54(1/3): 81-103.

*Türkay, M. 1973b. Bemerkungen zu einigen Landkrabben (Crustacea, Decapoda). Bulletin du Muséum national d'histoire naturelle, (3)142 (Zool.106): 969-980, figs.1, 2, pls. 1, 2.

Türkay, M. 1974a. Die Gecarcinidae Asiens und Ozeaniens (Crustacea: Decapoda). Senckenbergiana biologica, 55(4/6): 223-259.

*Türkay, M. 1974b. Die Grapsidae: Grapsinae des naturhistorischen Museums Genf, mit einer Bestimmungstabelle der rezenten Gattungen (Crustacea, Decapoda). Revue Suisse de Zoologie, 81(1): 137-148, pl. 1.

*Türkay, M. 1975. Zur Kenntnis der Gattung Euchirograpsus mit Bemerkungen zu Brachygrapsus and Litocheira (Crustacea: Decapoda). Senckenbergiana biologica, 52(1/3): 103-132.
**Türkay, M. 1978. Die Identität von Pseudothelphusa complanata Rathbun 1905 mit Bemerkungen zu Pseudothelphusa (Tehuana) Rodriguez and Smalley 1969 (Crustacea: Decapoda: Pseudothelphusidae). Senckenbergiana biologica, $59(1 / 2): 143-150$.

**Türkay, M. and Diesel, R. 1994. Description of a new species of Sesarma from Jamaica with notes on its occurrence and biology. Senckenbergiana biologica, 74(1/2): 157-161.

Weber, F. 1795. Nomenclator entomologicus secundum entomologiam systematicum ill. Fabricii adjectis speciebus recens detectis et varietatibus. Pp. i-viii, 1-172. (Chilonii and Hamburgi).

White, A. 1847. Short descriptions of some new species of Crustacea of the British Museum. Proceedings of the Zoological Society of London, 1847: 84-86.

Yeo, D.C.J.; Ng, P.K.L.; Cumberligde, N.; Magalhães, C.; Daniels, S.R. and Campos, M.R. 2008. Global diversity of crabs (Crustacea: Decapoda: Brachyura) in freshwater. Hydrobiologia, 595: 275-286.

Zimmer, C. 1912. Beitrag zur kentniss der Süsswasser dekapoden Kolumbiens. In: O. Fuhrmann and E. Mayor (eds), Voyage d'exploration scientifique en Colombie. Mémoires de la Société neuchateloise des Sciences Naturelles, 5: 1-8.

Note:

* Michael's publications including New World decapods: Sakai and Türkay, 1977; Sakai and Türkay, 2012; Sakai and Türkay, 2013; Sakai and Türkay, 2014; Sakai, Türkay and Yang, 2006; Türkay, 1971a; Türkay, 1971b; Türkay, 1973b; Türkay, $1974 b ;$ Türkay, 1975. ** Michael's publications exclusively on New World taxa: Campos and Türkay, 1989; Magalhães, Campos and Türkay, 2013; Magalhães and Türkay, 1986; Magalhães and Türkay, 1996a; Magalhãe and Türkay, 1996b; Magalhães and Türkay, 1996c; Magalhães and Türkay, 2008a; Magalhães and Türkay, 2008b; Magalhães and Türkay, 2008c; Magalhães and Türkay, 2010; Magalhães and Türkay, 2012; Magalhães, Türkay and Means, 2009; Rodriguez and Türkay, 1978; Schubart, Reimer, Diesel and Türkay, 1997; Türkay, 1967; Türkay, 1968; Türkay, 1970; Türkay, 1972; Türkay, 1978; Türkay and Diesel, 1994. 